\title{
Çermail Armut Marmelatı Kullanılarak Üretilen Yoğurtların Bazı Kalite Kriterleri Üzerine Bir Araştırma
}

\author{
Filiz YANGILAR* \\ Erzincan Binali Yıldırım Üniversitesi, Sağlık Bilimleri Fakültesi, Beslenme ve Diyetetik Bölümü, \\ Erzincan, Türkiye \\ (ORCID: 0000-0001-6447-2419)
}

\begin{abstract}
$\ddot{O} \mathbf{z}$
Bu çalışmada $\% 5,10$ ve 15 oranında Çermail armut marmelatı ile zenginleştirilen yoğurtlar üretilerek $4^{\circ} \mathrm{C}$ 'de 21 gün süre ile depolanmış ve periyodun 1., 7., 14. ve 21. günlerinde bazı fizikokimyasal, mikrobiyolojik ve duyusal parametreleri incelenmiştir. Marmelat konsantrasyonunun artması $\mathrm{pH}$ ve serum ayrılması değerlerinde azalmalara ve depolama süresince de viskozite ve asitlik değerlerinde artmalara neden olmuştur. Kontrol grubuna oranla, marmelatlı yoğurtlarda depolama süresince Lactobacillus delbrueckii subsp. bulgaricus sayısında düşme ve Streptococcus thermophilus sayılarında ise dalgalanmalar tespit edilmiştir. \%15 armut marmelatl grupta depolama süresince Lactobacillus delbrueckii subsp. bulgaricus sayısı 8,20-8,29 log kob/gr ve Streptococcus thermophilus sayısı 8,29-8,63 log kob/gr arasında bulunmuştur. Armut marmelat konsantrasyonu arttıkça yoğurt bakteri sayılarında azalma olduğu tespit edilmiştir. Özellikle kontrol grubu ve \%10 oranındaki marmelat katkılı örnekler panelistler tarafindan daha çok beğenilmiştir. Araştırma sonuçları, Erzincan ilinde yetişen Çermail armutunun fonksiyonel yoğurt üretiminde ürün çeşitliliği açısından kullanılabileceğini göstermiştir.
\end{abstract}

Anahtar kelimeler: Çermail armutu, Duyusal özellikler, Serum ayrılması, Viskozite, Yoğurt.

\section{A Research on Some Quality Criteria of Yoghurts Produced Using Çermail Pear Marmalade}

\begin{abstract}
In this study, by producing yoghurt enriched with 5, 10 and $15 \%$ Çermail pear marmalade and stored at $4^{\circ} \mathrm{C}$ for 21 days, some physicochemical, microbiological, sensory parameters at the 1st, 7th, 14th and 21st days of storage were investigated. The $\mathrm{pH}$ and syneresis values of samples decreased with increasing marmalade ratios, whereas viscosity and acidity values increased during storage. When compared to the control group, Lactobacillus delbrueckii subsp. bulgaricus counts at the marmalade added samples a decreasing and fluctuations in the count of Streptococcus thermophiles during storage were determined. In the 15\% pear marmalade group, Lactobacillus delbrueckii subsp. bulgaricus count was found between 8.20-8.29 log cfu/gr and Streptococcus thermophilus count between 8.29-8.63 log cfu/gr. It was determined that as the pear marmalade concentration increased, the number of yoghurt bacteria decreased. The control group and the $10 \%$ marmalade added samples was the most especially liked by panellists. Research results showed that Çermail pear grown in Erzincan province can be used in functional yogurt production in terms of product variety.
\end{abstract}

Keywords: Çermail pear, Sensory properties, Syneresis, Viscosity, Yogurt.

\section{Giriş}

Kardiyometabolik hastalıklar için obezite, tip 2 diyabet, dislipidemi ve hipertansiyon en önemli risk faktörleridir. Batı diyetine özgü veya gıda esaslı diyet rehberlerinde süt ürünlerinin bu hastalıklar üzerinde yararlı etkiler sağladığı bilgisi yer almaktadır [1,2]. Epidemiyolojik çalışmalarda yoğurtun diğer süt ürünlerine göre kalbi korumada [3], tip 2 diyabeti azaltmada [4], vücut ağırlık ve şekli üzerinde

*Sorumlu yazar:__yangilar@hotmail.com

Geliş Tarihi: 16.01.2021, Kabul Tarihi: 21.03.2021 
daha olumlu sonuçlar gösterdiğini ortaya koymuştur [5-7]. Son y1llarda kalite standartları yüksek bir hayat beklentisi gida ve sağlık arasındaki interaksiyonun tekrar gözden geçirilmesine ve üreticileri de tüketici sağlığını koruma doğrultusundaki üretim hattına yöneltmeye neden olmuştur. Bunun için kefir ve yoğurt gibi süt ürünlerini de kapsayan ve super gıdalar olarak adlandırılan fonksiyonel ürünler hazırlanılmaya başlanılmıştır $[8,9]$. Yoğurt yüksek kaliteli protein, kalsiyum, potasyum, çinko, fosfor, magnezyum gibi minerallerle birlikte A, Riboflavin (B2), kobalamin (B12) ve pantotenik asit (B5 vitamini) gibi mikro besinleri içeren besinsel açıdan zengin bir gıdadır [10-12]. Bu kadar değerli bir ürün olan yoğurdun fonksiyonel ve besinsel değerlerinin zenginleştirilmesi üzerine yapılan çalışmalar içerisinde meyve ilavesi oldukça önemli bir yer oluşturmaktadır. Meyveler geçen birkaç yüzyıl içinde; kuru öksürük, boğaz ağrısı ve susuzluğu gidermek için ilaç gibi kullanılmıştır. Ayrıca sakkaroza göre düşük kalorili ve yüksek tatlılığa sahip doğal bir tatlandırıcı olarak da kullanılmıştır $[13,14]$. Bu meyveler arasında armut kendine ait tat, yapı, koku ve aroması açısından tercih oranı yüksek bir çeşittir. Ülkemizde taze, kurutularak, püre, konsantre nektar, armut suyu, pulplu meyve suyu gibi farklı tüketim şekillerine sahiptir $[15,16]$. Meyve; diyet lifi, C ve B6 vitaminleri, mağnezyum ve potasyum açısındanda zengindir $[17,18]$.

Farklı ekolojik şartlara sahip olan ülkemiz birçok meyve türünde olduğu gibi armutta da mahalli çeşitlerinin belirli alanlarda toplanmasını sağlamışırı $[19,20]$. Bu durum, mahalli armut yetiştirme noktalarından birisini oluşturan Erzincan ovası armut çeşitlerinden Çermailinde mahalli bir özellik kazanmasına neden olmuştur [21]. Bu çalışmada Erzincan'ın standart armut çeşiti yetiştiriciliğinin yaygınlaşması ile üretimi artık fazla yapılmayan kültürel mirasımızı oluşturan mahalli armut çeşitlerinden olan Çermail armutu marmelatının farklı konsantrasyonları kullanılarak üretilen yoğurtların fizikokimyasal, mikrobiyolojik ve duyusal özellikleri araştırılmıştır.

\section{Materyal ve Metot}

\subsection{Materyal}

Araştırmada yoğurt üretimi için Erzincan ilinde faaliyet gösteren Balacan Hayvan Çiftliğinden 2 Kasım 2018 y1lında tedarik edilen inek sütleri kullanılmıştır. Üretimde DVS YC-180 (Peyma-Chr. Hansen, İstanbul) starter kültürü kullanılmıştır. 2018 yılının Ekim ayında hasad edilen Çermail armutu ve şeker Erzincan piyasasından temin edilmiştir.

\subsection{Armut Marmelatının Hazırlanması}

Meyveler iyice yıkandıktan sonra kabukları soyulup çekirdekleri çıkarılarak püre haline getirildi. Püreye $\% 25$ oranında şeker ilave edildikten sonra $90 \pm 1^{\circ} \mathrm{C}^{\prime}$ de 5 dakika termometre ile sıcaklık kontrolü takip edilip sıcaklık sensörlü manyetik karıştırıcıda (Daihan Scientific Wisestir MSH-20A, Korea) pastörize edildi. Hazırlanılan armut marmelatı steril cam kavanozlara aktarılarak üretimde kullanılmaya hazır hale getirildi.

\subsection{Deneme Yoğurt Üretimi}

Çĭg süte (kuru madde \%11,5, yağ \%3,05, kül \%0,68, protein \%3,0, asitlik \%0,16), 90 ${ }^{\circ} \mathrm{C}$ 'de 10 dakika sıcaklık sensörlü manyetik karıştırıcıda (Daihan Scientific Wisestir MSH-20A, Korea) 1sıl işlem uygulanmış ve daha sonra hızlıca $45^{\circ} \mathrm{C}$ 'ye kadar soğutulmuş ve $\% 2$ oranında starter kültür inoküle edilerek dört eşit kısma ayrılmıştır. Birinci kısım kontrol (K), İkinci \%5 (A1), üçüncü \%10 (A2) ve dördüncü \%15 (A3) oranında Çermail armut marmelatı ilave edilerek hazırlanmıştır. Daha sonra, 150 ml'lik kaplara dolum yapılarak $42^{\circ} \mathrm{C}^{\prime}$ de 3,5 saat süreyle inkübasyona bırakılmıştır. İnkübasyon sonrasında, deneme örnekler $4^{\circ} \mathrm{C}^{\prime}$ ye kadar soğutulmuş ve bu sıcaklıkta 21 gün süre ile depolanarak 1 ., 7., 14. ve 21. günlerinde analizleri yapılmıştır [22].

\subsection{Fizikokimyasal ve Mikrobiyolojik Analizler}

Yoğurt örneklerinin kuru madde miktarı [23], yağ oranı ve titrasyon asitliği (\% laktik asit) Kurt ve ark. [24] metoduna göre yapılmıştır. Deneme örneklerin pH değeri pH metre (Starter 3000, Ohaus, 
Parsippany, NJ, USA) ile ölçülmüş̧ür. Yoğurtların viskozite tayini Brookfield marka viskozimetre (Model DV-1; Brookfield Engineering Laboratories, Inc., MA, USA) kullanılarak analiz edilmiş ve sonuçlar cP olarak tespit edilmiştir [25]. Deneme örneklerdeki serum ayrılması, $+4^{\circ} \mathrm{C}$ 'de $25 \mathrm{~g}$ yoğurt örneğinin kaba filtre kâğıdı kullanılarak süzülüp ayrılan serumun ml olarak tespit edilmesi ile belirlenmiştir [26]. Deneme yoğurt örneklerinde Lactobacillus bulgaricus ve Streptococcus thermophilus bakterilerin sayımı Vinderola and Reinheimer [27] metoduna göre yapılmıştır.

\subsection{Duyusal analizler}

Deneme örneklerin duyusal incelenmesinde 6 kişilik panelist ekibi "Renk", "Tat", "Koku", "Tekstür" ve "Genel Kabul Edilebilirlik" olmak üzere beş farklı parametreye göre değerlendirmeyi yapmış ve depolama boyunca oluşan değişimler için verilen puanlara göre sonuçlar belirlenmiştir [28].

\section{6. İstatistiksel Değerlendirme}

IBM SPSS 22 paket programı kullanılarak verilerin varyans analizi yapılmıştır. Önemli farklılıkların belirlenmesinde Duncan Çoklu Karşılaştırma Testi uygulanmıştır.

\section{Bulgular ve Tartışma}

Çermail armut marmelatlı yoğurt örneklerine ait bazı fizikokimyasal özellikler Tablo 1'de verilmiştir.

Tablo 1. Çermail armut marmelatlı yoğurtların bazı fizikokimyasal analiz sonuçları

\begin{tabular}{ccccc}
\hline & \multicolumn{4}{c}{ Yoğurt Örnekleri } \\
\hline Analizler & $\mathbf{K}$ & $\mathbf{A 1}$ & $\mathbf{A 2}$ & $\mathbf{A 3}$ \\
\hline Kuru madde (\%) & $13,15 \pm 0,02^{\mathrm{a}}$ & $14,01 \pm 0,05^{\mathrm{b}}$ & $14,30 \pm 0,12^{\mathrm{c}}$ & $14,61 \pm 0,06^{\mathrm{d}}$ \\
Yă̆ (\%) & $3,38 \pm 0,12^{\mathrm{c}}$ & $3,30 \pm 0,05^{\mathrm{b}}$ & $3,29 \pm 0,02^{\mathrm{b}}$ & $3,21 \pm 0,08^{\mathrm{a}}$ \\
pH & $4,11 \pm 0,16^{\mathrm{b}}$ & $4,22 \pm 0,05^{\mathrm{c}}$ & $4,03 \pm 0,12^{\mathrm{a}}$ & $4,21 \pm 0,05^{\mathrm{c}}$ \\
Titrasyon asitliği (\%) & $1,07 \pm 0,08^{\mathrm{a}}$ & $1,12 \pm 0,05^{\mathrm{ab}}$ & $1,34 \pm 0,16^{\mathrm{c}}$ & $1,17 \pm 0,18^{\mathrm{b}}$ \\
Serum ayrıması (mL/25 g) & $6,94 \pm 0,53^{\mathrm{b}}$ & $6,58 \pm 0,34^{\mathrm{b}}$ & $5,38 \pm 0,16^{\mathrm{a}}$ & $5,71 \pm 0,67^{\mathrm{a}}$ \\
\hline
\end{tabular}

*Aynı satırdaki farklı harfler istatistiksel olarak farklılığ ifade etmektedir ( $<<0,05)$. K: Kontrol, A1: \%5 Çermail armut marmelatlı yoğurt, A2: \%10 Çermail armut marmelatlı yoğurt, A3: \%15 Çermail armut marmelatlı yoğurt.

Yoğurt örneklerinin kuru madde oranı en düşük \%13,15 K grubunda ve en yüksek \%14,61 olarak A3 grubunda tespit edilmiştir (Tablo 1). Marmelat oranı arttıkça yoğurtların kuru madde oranlarında artma görülmüştür. Yoğurtların kuru madde oranları arasındaki fark istatistiksel olarak önemli bulunmuştur $(\mathrm{p}<0.05)$. Wulansari ve Kusmayada [29]'nın farklı meyve ilaveli inek sütünden elde edilen yoğurtların sırasıyla ejder meyvesi, mango, elma ve muz katılan yoğurtlarda kuru madde sonuçlarını \%13,628; \%13,108; \%14,376 ve \%14,376 olarak bulmuşlardır.

Tablo 1'de verildiği gibi yağ oranları $\mathrm{K}$ grubunda \%3,38 ve A3 grubunda \%3,21 olarak bulunmuş ve depolama süresince örneklerin yă̆ değerlerinde azalma görülmüsstür. Yağ oranında depolama süresince örneklerde istatistiksel olarak önemli $(\mathrm{p}<0,05)$ değişimler olduğu gözlenmiş olup en yüksek yă̆ oranı depolamanın 1 ve 14. günlerinde K grubunda tespit edilmiştir. Meyveli yoğurtlar üzerinde yapılan çalışmalarda yağ oranının meyve ilavesi ile düştüğü bildirilmiştir [30, 31]. Araştırma sonucunda elde edilen verilerin daha önce yapılan araştırmalarla uyum içerisinde olduğu gözlenmiştir.

Depolama süresince marmelatlı yoğurtların $\mathrm{pH}$ oranında azalma tespit edilmiş ve istatistiksel analizlere göre depolamanın yoğurtların $\mathrm{pH}$ değerleri üzerine etkisi önemli bulunmuştur $(\mathrm{p}<0,05)$. Vahedi ve ark. [32] elma ve çilek ile zenginleştirdikleri yoğurt örneklerinin depolama süresi boyunca pH değerlerinde azalma olduğunu ancak \%10 elma katkı1ı ürettikleri yoğurt örneklerinde depolamanın 21. gününden ve $\% 13$ çilek katk1lı örneklerin ise 14. günden sonra $\mathrm{pH}$ değerlerinde artma olduğunu bildirmişlerdir. Bunun da sebebi olarak mikroorganizmaların faaliyetinden kaynaklanmış olabileceğini öne sürmüşlerdir. Araştırmacılar mayalar tarafından ilk olarak ortamdaki organik asit ve şekerin kullanılmasının sonucunda $\mathrm{pH}$ değerinde düşme olduğunu ve şekerin bitmesi sonucunda mevcut proteinlerin kullanılmaya başlanması ile de zamanla $\mathrm{pH}$ değerinde bir artma meydana geldiğini paylaşmışlardır [33, 34]. 
Armut marmelatlı yoğurtların titrasyon asitliği \%1,07-1,34 arasında değişmiştir. Depolama periyodu ve marmelat katkısının titrasyon asitliği üzerine istatistiksel açıdan $\mathrm{p}<0,05$ düzeyinde etkili olduğu tespit edilmiştir. Temiz ve ark. [35] \%5, \%10, \%15 ve \%20 oranlarında yenidünya marmelat1 kullanarak hazırladıkları yoğurtlarda marmelat miktarındaki artışa bağlı olarak titrasyon asitliği değerlerinde artış olduğunu rapor etmişlerdir.

Marmelatlı yoğurt örneklerinde ayrılan serum miktarı en düşük depolamanın 14. günde A2 yoğurtta $5,18 \mathrm{~mL} / 25 \mathrm{~g}$ olarak bulunurken en yüksek 7. gününde $\mathrm{K}$ grup örneğinde 7,46 mL/25 g bulunmuştur. Marmelat konsantrasyonu ve depolama süresi örneklerin serum ayrılması değerini istatistiksel olarak önemli düzeyde etkilemiştir $(p<0,05)$. Tarakçı [36] kivi marmelatlı yoğurtlarda marmelat konsantrasyonundaki artış ve depolama süresine bağlı olarak serum ayrılmasının azaldığını belirtmiştir.

Marmelatlı yoğurtların viskozite değerleri arasındaki farklılık istatistiksel olarak önemli bulunmuştur $(p<0,05)$. Marmelat ve depolama süresi arasındaki interaksiyon Şekil 1'de verilmiştir. Çelik ve ark. [37] kızılcık püresi ve şeker ilavesi yaparak ürettikleri yoğurt örneklerinde serum ayrılması değerlerinde artış olduğu ve viskozite değerlerinde de düşme olduğunu tespit etmişlerdir. Yaygın [38], meyvelerde pektinin şişerek kıvamda artış sağladığını ve bunun da viskozitede artışa neden olduğunu paylaşmıştır. Araştırmacıların sonuçları çalışma sonuçlarıyla uyum göstermektedir.

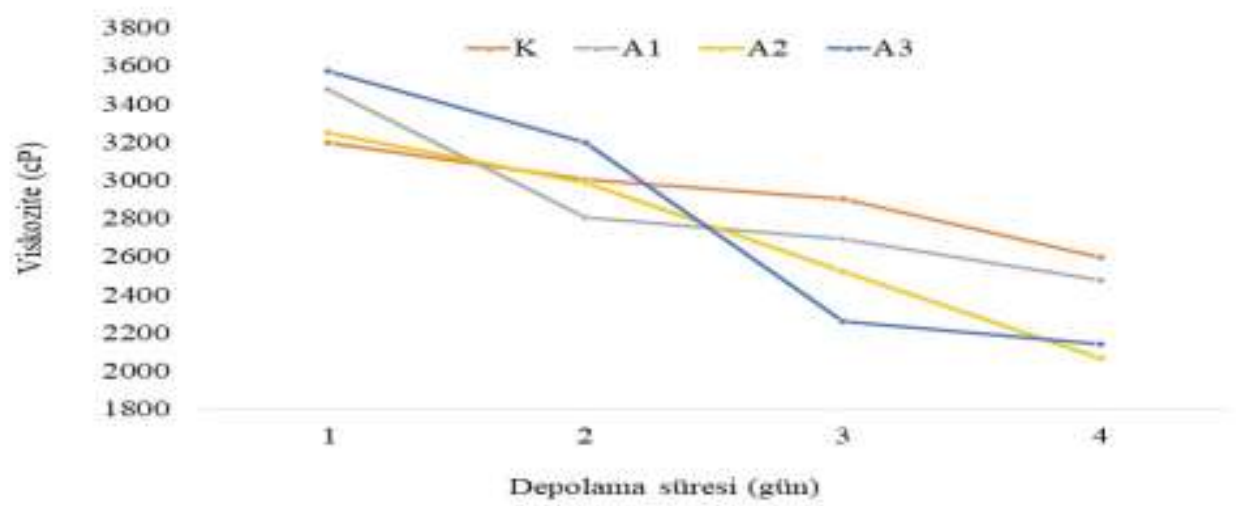

Şekil 1. Çermail armut marmelatlı yoğurtların depolama süresince tespit edilen $\mathrm{pH}$ değerleri. K: Kontrol, A1: \%5 Çermail armut marmelatlı yoğurt, A2: \%10 Çermail armut marmelatlı yoğurt, A3: \%15 Çermail armut marmelatlı yoğurt.

Çermail armut marmelatlı yoğurtların bazı mikrobiyolojik analiz sonuçları Tablo 2'de verilmiştir. Tüm örneklere ait laktik asit bakteri sayıları, depolama periyodu boyunca azalmış ve 21 . günde en düşük düzeye ulaşmıştır.

Tablo 2. Çermail armut marmelatlı yoğurtların bazı mikrobiyolojik analiz sonuçları

\begin{tabular}{|c|c|c|c|c|c|}
\hline \multirow[t]{2}{*}{ Analizler } & \multirow{2}{*}{$\begin{array}{l}\text { Depolama } \\
\text { süresi (gün) }\end{array}$} & \multicolumn{4}{|c|}{ Yoğurt Örnekleri } \\
\hline & & $\mathbf{K}$ & A1 & A2 & A3 \\
\hline Lactobacillus delbrueckii & 1 & $8,60 \pm 0,28^{\mathrm{a}, \mathrm{A}}$ & $8,63 \pm 0,02^{\mathrm{a}, \mathrm{C}}$ & $8,37 \pm 0,00^{\mathrm{a}, \mathrm{C}}$ & $8,25 \pm 0,01^{\mathrm{a}, \mathrm{B}}$ \\
\hline \multirow{4}{*}{$\begin{array}{l}\text { ssp. bulgaricus } \\
\text { (log kob/gr) }\end{array}$} & 7 & $8,40 \pm 0,02^{\mathrm{b}, \mathrm{A}}$ & $8,32 \pm 0,01^{\mathrm{a}, \mathrm{B}}$ & $8,39 \pm 0,00^{\mathrm{b}, \mathrm{C}}$ & $8,27 \pm 0,00^{\mathrm{a}, \mathrm{BC}}$ \\
\hline & 14 & $8,57 \pm 0,03^{\mathrm{b}, \mathrm{A}}$ & $8,27 \pm 0,02^{\mathrm{a}, \mathrm{AB}}$ & $8,20 \pm 0,00^{\mathrm{a}, \mathrm{B}}$ & $8,20 \pm 0,00^{\mathrm{a}, \mathrm{A}}$ \\
\hline & 21 & $8,51 \pm 0,02^{\mathrm{c}, \mathrm{A}}$ & $8,22 \pm 0,03^{\mathrm{b}, \mathrm{A}}$ & $8,07 \pm 0,03^{\mathrm{a}, \mathrm{A}}$ & $8,29 \pm 0,00^{\mathrm{b}, \mathrm{C}}$ \\
\hline & 1 & $8,39 \pm 0,00^{\mathrm{c}, \mathrm{B}}$ & $8,36 \pm 0,01^{\mathrm{b}, \mathrm{A}}$ & $8,47 \pm 0,00^{\mathrm{d}, \mathrm{A}}$ & $8,29 \pm 0,00^{\mathrm{a}, \mathrm{D}}$ \\
\hline \multirow{3}{*}{$\begin{array}{c}\text { Streptococcus } \\
\text { thermophilus } \\
\text { (log kob/gr) }\end{array}$} & 7 & $8,52 \pm 0,00^{\mathrm{a}, \mathrm{C}}$ & $8,67 \pm 0,03^{b, C}$ & $8,70 \pm 0,00^{\mathrm{b}, \mathrm{B}}$ & $8,47 \pm 0,02^{\mathrm{a}, \mathrm{C}}$ \\
\hline & 14 & $8,37 \pm 0,02^{\mathrm{a}, \mathrm{B}}$ & $8,42 \pm 0,01^{\mathrm{a}, \mathrm{B}}$ & $8,81 \pm 0,02^{\mathrm{b}, \mathrm{C}}$ & $8,39 \pm 0,01^{\mathrm{a}, \mathrm{B}}$ \\
\hline & 21 & $8,25 \pm 0,02^{\mathrm{a}, \mathrm{A}}$ & $8,45 \pm 0,00^{\mathrm{b}, \mathrm{B}}$ & $8,70 \pm 0,00^{\mathrm{d}, \mathrm{B}}$ & $8,63 \pm 0,03^{\mathrm{c}, \mathrm{A}}$ \\
\hline
\end{tabular}

${ }^{\mathrm{a}-\mathrm{d}}$ Aynı satırdaki farklı küçük harfler istatistiksel olarak ortalama değerler arasındaki farklılığı gösterir $(\mathrm{p}<0,05)$.

A-D Aynı sütundaki farklı büyük harfler ortalama değerler arasındaki istatistiksel farklığı gösterir $(p<0,05)$. K:

Kontrol, A1: \%5 Çermail armut marmelatlı yoğurt, A2: \%10 Çermail armut marmelatlı yoğurt, A3: \%15 Çermail armut marmelatlı yoğurt. 
Tablo 2'de yer alan verilere göre MRS agarda gelişen en fazla Lactobacillus delbrueckii ssp. bulgaricus sayıs1 depolamanın 1. gününde A1 grubunda iken (8,63 log kob/gr) en az bakteri sayıs1 depolamanın 21. gününde A2 grubunda $(8,07 \mathrm{log} \mathrm{kob} / \mathrm{gr})$ tespit edilmiştir. M17 agarda gelişen Streptococcus thermophilus sayıları ise en fazla depolamanın 14. gününde A2 grubunda $(8,81 \mathrm{log}$ kob/gr) olarak bulunurken en az depolamanın 21. gününde $\mathrm{K}$ grubunda $(8,25 \mathrm{log}$ kob/gr) belirlenmiştir. Ertem ve Çakmakçı [39] \%5 ve \%10 gobdin ilavesi yapılmış yoğurtlarda sırasıyla, Laktobasil cinsi laktik asit bakteri sayısını 7,15- 8,81 log kob/gr ve Streptokok cinsi laktik asit bakteri sayısını ise 7,21$8,66 \log \mathrm{kob} / \mathrm{gr}$ şeklinde tespit etmiştir. Bu araştırma bulguları araştırmacının bildirdiği sonuçlarla uyum göstermektedir. Çermail armut marmelatlı yoğurtların duyusal değerlerinin depolama süresince değişimleri Şekil 2'de verilmiştir.
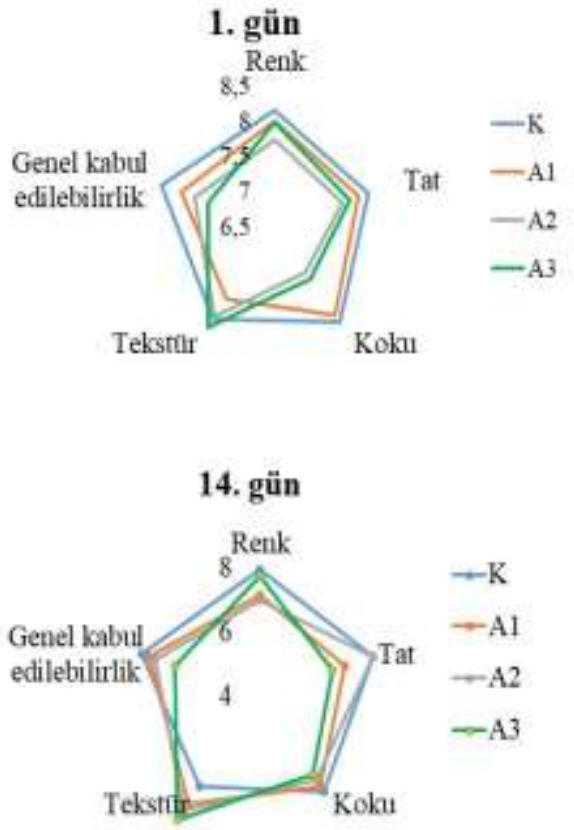
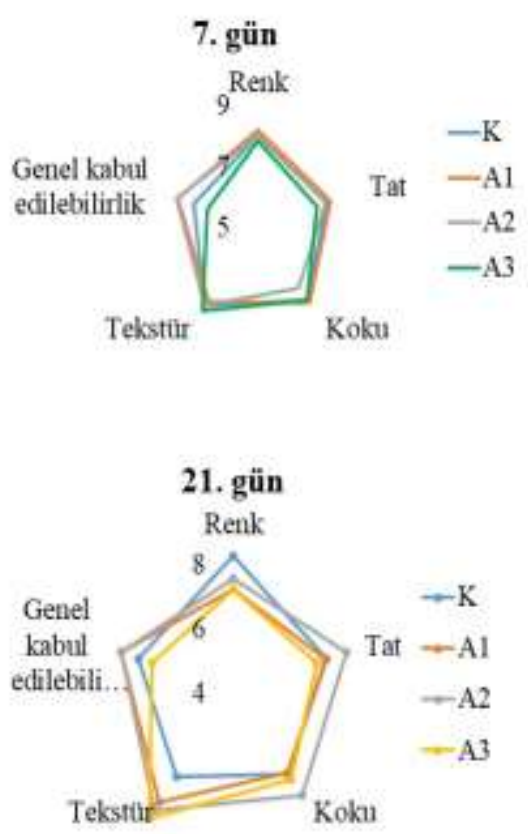

Şekil 2. Çermail armut marmelatlı yoğurtların depolama sürelerine göre duyusal analiz sonuçları. K: Kontrol, A1: \%5 Çermail armut marmelatlı yoğurt, A2: \%10 Çermail armut marmelatlı yoğurt, A3: \%15 Çermail armut marmelatlı yoğurt.

Çermail armut marmelatlı yoğurtların renk puanları K grubu örnekten daha düşük puan almıştır. Marmelat konsantrasyonunun yoğurtların renk puanına etkisi istatistiksel açıdan önemli bulunmuştur $(\mathrm{p}<0,05)$. Marmelatlı yoğurtların tat puanları incelendiğinde en yüksek puan depolamanın 21. günündeki A2 grubunda $(8,07)$, en düşük puan ise depolamanın 14. gününde $A 3$ grubuna $(6,54)$ ait olduğu görülmektedir. Marmelat ilavesi depolama süresince panelistler tarafindan örneklerin düşük koku puanları almasına neden olmuştur. Depolama süresinin tüm yoğurt gruplarının tekstür değerleri üzerindeki etkisi önemli bulunmuştur $(\mathrm{p}<0,05)$. Çermail marmelatlı yoğurtların genel kabul edilebilirlik puanları karşılaştıılddı̆ı̆nda en yüksek puanın depolamanın 1. gününde $K$ grubunda en düşük puan ise depolamanın 21. gününde $A 3$ grubuna ait olduğu tespit edilmiştir. Bartoo and Badrie [40] $\% 15$ ve \%20 golden elma nektarı katkılı yoğurtlarda \%15 ve \%20'li yoğurtların kontrol yoğurduna göre duyusal olarak daha çok beğenildiğini bildirmişlerdir.

\section{Sonuç ve Öneriler}

Marmelat oranının artması ile örneklerin kuru madde oranlarında artma, titrasyon asitliği, yağ ve serum ayrılması değerlerinde ise düşme tespit edilmiştir. Viskozite ve $\mathrm{pH}$ değerleri depolama süresince azalmıştır. Marmelat konsantrasyonunun laktik asit bakteri sayılarının terapötik etki oluşturduğu sınır olan $10^{6} \mathrm{kob} / \mathrm{g}$ minimum sayısının üzerinde bulunduğu görülmüştür. Duyusal değerlendirmede ise $\% 10$ 
armut marmelatlı örneğin panelistler tarafından daha çok tercih edildiği belirlenmiştir. Armut marmelatlı yoğurt üretimini içeren çok sınırlı çalışma söz konusu olup genellikle bilinen meyveler (elma, muz, karayemiş, hurma, kayısı, çilek, kızılcık, vb.) üretimde tercih edildiği için Erzincan'da yetişen kokulu, sulu ve aromatik bir armut çeşidinin kullanılarak farklı bir ürün grubunun hazırlanabileceği bu çalışma da tespit edilmiştir. Böylece mutfak kültürümüzün önemli bir ürününü oluşturan yoğurdun sürekli artan tüketim talebi doğrultusunda her yaştan birey tarafindan sevilerek tüketilebilecek farklı bir ürün çeşidi piyasaya kazandırılmış olacaktır.

\section{Yazarların Katkısı}

Bu makaledeki tüm katkı yazara aittir.

\section{Çıkar Çatışması Beyanı}

Yazarlar arasında herhangi bir çıkar çatışması bulunmamaktadır.

\section{Araştırma ve Yayın Etiği Beyanı}

Yapılan çalışmada araştırma ve yayın etiğine uyulmuştur.

\section{Kaynaklar}

[1] Bohl M., Bjørnshave A., Larsen M.K., Gregersen S., Hermansen K. 2017. The effects of proteins and medium-chain fatty acids from milk on body composition, insulin sensitivity and blood pressure in abdominally obese adults. European Journal of Clinical Nutrition,71 (1): 76-82.

[2] Fernandez M.A., Panahi S., Daniel N., Tremblay A., Marette A. 2017. Yogurt and cardiometabolic diseases: a critical review of potential mechanisms. Advances in Nutrition, 8 (6): 812-829.

[3] Dalmeijer G.W, Struijk E.A., Van Der Schouw Y.T., Soedamah-Muthu S.S., Verschuren W.M., Boer J.M., Geleijnse J.M, Beulens J.W. 2013. Dairy intake and coronary heart disease or stroke a population-based cohort study. International Journal of Cardiology, 167 (3): 925-929.

[4] Chen M., Sun Q., Giovannucci E., Mozaffarian D., Manson J.E., Willett W.C., Hu F.B. 2014. Dairy consumption and risk of type 2 diabetes: 3 cohorts of US adults and an updated metaanalysis. BMC Medicine, 12 (1): 215.

[5] Wang H., Livingston K.A., Fox C.S., Meigs J.B., Jacques P.F. 2013. Yogurt consumption is associated with better diet quality and metabolic profile in American men and women. Nutrition Research, 33 (1): 18-26.

[6] Mirmiran P., Esmaillzadeh A., Azizi F. 2005. Dairy consumption and body mass index: an inverse relationship. International Journal of Obesity, 29 (1): 115-121.

[7] Panahi S., Doyon C.Y., Després J.P., Pérusse L., Vohl M. C., Drapeau V., Tremblay A. 2018. Yogurt consumption, body composition, and metabolic health in the Quebec Family Study. European Journal of Nutrition, 57 (4): 1591-1603.

[8] van den Driessche J.J., Plat J., Mensink R.P. 2018. Effects of superfoods on risk factors of metabolic syndrome: A systematic review of human intervention trials. Food \& Function, 9 (4): 1944-1966.

[9] Baspinar B., Güldaş M. 2020. Traditional plain yogurt: a therapeutic food for metabolic syndrome? Critical Reviews in Food Science and Nutrition, 1-15.

[10] Williams E.B., Hooper B., Spiro A., Stanner S. 2015. The contribution of yogurt to nutrient intakes across the life course. Nutrition Bulletin, 40 (1): 9-32.

[11] Keast D.R., Hill Gallant K.M., Albertson A.M., Gugger C.K., Holschuh N.M. 2015. Associations between yogurt, dairy, calcium, and vitamin D intake and obesity among U.S. children aged 8-18 years: NHANES, 2005-2008. Nutrients, 7 (3): 1577-1593.

[12] Donovan S.M., Hutkins R. 2018. Introduction to the fifth global summit on the health effects of yogurt. Nutrition Reviews, 76 (Supplement-1): 1-3. 
[13] Lu F., Li D., Fu C., Liu J., Huang Y., Chen Y., Nohara T. 2012. Studies on chemical fingerprints of Siraitia grosvenorii fruits (Luo Han Guo) by HPLC. Journal of Natural Medicines, 66 (1): 7076.

[14] Abdel-Hamid M., Romeih E., Huang Z., Enomoto T., Huang L., Li L. 2020. Bioactive properties of probiotic set-yogurt supplemented with Siraitia grosvenorii fruit extract. Food Chemistry, 303: 125400.

[15] Özaydın A.G., Özçelik S. 2014. Ankara armudunun bazı fizikokimyasal özellikleri üzerine fırında kurutma işleminin etkisi. Akademik Gıda, 12 (4): 17-26.

[16] Şengül M., Topdaş E.F., Doğan H., Serencam H. 2018. Artvin İlinde Geleneksel Olarak Üretilen Bazı Marmelat Çeşitlerinin Çeşitli Fiziksel ve Kimyasal Özellikleri ile Antioksidan Aktiviteleri ve Fenolik Profillerinin Araştırılması. Akademik Gıda, 16 (1): 51-59.

[17] Lutovska M., Mitrevski V., Pavkov I., Mijakovski V., Radojčin M. 2016. Mathematical modelling of thin layer drying of pear. Chemical Industry and Chemical Engineering Quarterly, 22 (2): 191199.

[18] İzli G. 2018. Farklı Kurutma Uygulamalarının Armut Meyvesinin Bazı Kalite Özellikleri Üzerine Etkileri. Türk Tarım-Gıda Bilim ve Teknoloji Dergisi, 6 (4): 479-485.

[19] Karlıdă̆ H., Eşitken A. 2006. Yukarı Çoruh vadisinde yetiştirilen elma ve armut çeşitlerinin bazı pomolojik özelliklerinin belirlenmesi. Yüzüncü Yıl Üniversitesi Tarım Bilimleri Dergisi, 16 (2): 93-96.

[20] Balta M.F., Üç L., Karakaya O. 2019. Şebinkarahisar (Giresun) İlçesinde Seçilen Alişar Armut Klonlarının Bazı Meyve Özellikleri. Uluslararası Tarım ve Yaban Hayatı Bilimleri Dergisi, 5 (1): 31-37.

[21] Gültekin L. 2015. Erzincan ovasında yetiştirilen Çermail armut çeşidinde üstün vasıflı tiplerin seçimi. Yüksek Lisans Tezi, Atatürk Üniversitesi, Fen Bilimleri Enstitüsü, Erzurum.

[22] Tamime A.Y., Robinson R.K. 1985. Yogurt Science and Technology. Pergamon Press, Oxford.

[23] AOAC. 1990. Official Methods of Analysis. Changes in Official Methods of Analysis Made at the Annual Meeting. Supplement (Vol. 15). Association of Official Analytical Chemists.

[24] Kurt A., Çakmakçı S., Çağlar A. 2007. Süt ve mamulleri muayene ve analiz metotları rehberi. Atatürk Üniversitesi Ziraat Fakültesi Yayınları, Erzurum, 18: 238.

[25] Gassem M.A., Frank J.F. 1991. Physical properties of yogurt made from milk treated with proteolytic enzymes. Journal of Dairy Science, 74 (5): 1503-1511.

[26] Atamer M., Sezgin E. 1986. Yoğurtlarda, Kuru madde Artırımının Pıhtının Fiziksel Özellikleri Üzerine Etkisi. Gıda, 11 (6).

[27] Vinderola C.G., Reinheimer J.A. 1999. Culture media for the enumeration of Bifidobacterium bifidum and Lactobacillus acidophilus in the presence of yoghurt bacteria. International Dairy Journal, 9 (8): 497-505.

[28] Lawless H.T., Heymann H. 2010. Sensory evaluation of food: principles and practices. Springer Science \& Business Media.

[29] Wulansari P.D., Kusmayadi A. 2016. Chemical Properties and Characteristics of Cow Milk Yogurt with Different Additional Fruit and Storage Time. Animal Production, 18 (2): 113-117.

[30] Aly S.A., Galal E.A., Elewa N.A. 2004. Carrot yoghurt: Sensory, chemical, microbiological properties and consumer acceptance. Pakistan Journal of Nutrition, 3 (6): 322-330.

[31] Ayar A., Sert D., Kalyoncu İ. 2005. Farklı Meyveler Kullanılarak Üretilen Yoğurtların Kimyasal, Reolojik ve Duyusal Özellikleri. Gida ve Yem Bilimi-Teknolojisi, 8.

[32] Vahedi N., Tehrani M.M., Shahidi F. 2008. Optimizing of fruit yoghurt formulation and evaluating its quality during storage. American-Eurasian Journal of Agricultural \& Environmental Sciences, 3 (6): 922-927.

[33] Frazier W.C., Westhhoff D.C. 1995. Food Microbiology. Mc Graw-Hill Book Company. Nova York, NY, 252-282.

[34] Jai J.M. 1990. Modern Food Microbiology. Chapman and Hall, 1: 2.

[35] Temiz H., Tarakci Z., Karadeniz T., Bak T. 2012. The effect of loquat fruit (Eriobotrya japonica) marmalade addition and storage time on phsico-chemical and sensory properties of yogurt. Tarım Bilimleri Dergisi, 18: 329-338. 
[36] Tarakçı Z. 2010. Influence of kiwi marmalade on the rheology characteristics, color values and sensorial acceptability of fruit yogurt. Kafkas Üniversitesi Veterinerlik Fakültesi Dergisi, 16 (2): 173-178.

[37] Çelik Ş., Bakırcı I., Şat I.G. 2006. Physicochemical and organoleptic properties of yogurt with cornelian cherry paste. International Journal of Food Properties, 9 (3): 401-408.

[38] Yaygın H. 1999. Yoğurt Teknolojisi. Akdeniz Üniversitesi Ziraat Fakültesi Gıda Mühendisliği Bölümü, Yayın No: 75, Antalya, 1-331.

[39] Ertem H., Çakmakçı S. 2018. Shelf life and quality of probiotic yogurt produced with Lactobacillus acidophilus and Gobdin. International Journal of Food Science \& Technology, 53 (3): 776-783.

[40] Bartoo S.A., Badrie N. 2005. Physicochemical, nutritional and sensory quality of stirred 'dwarf' golden apple (Spondias cytherea Sonn) yoghurts. International Journal of Food Sciences and Nutrition, 56 (6): 445-454. 